\title{
Executive Mobility and Minority Status
}

\author{
PAUL M. GUEST*
}

\begin{abstract}
We examine the mobility of minority executives, defined as ethnic minority and female executives, in publicly listed US firms. Minority executives as a whole experience lower promotion, higher demotion, and higher exit than Caucasian males. These differences are driven by female and African American executives. Female executives experience lower promotion and exit, whilst African Americans experience lower promotion, higher demotion, and higher exit. In contrast, Asian and Hispanic executives do not experience different mobility outcomes to Caucasian executives.
\end{abstract}

JEL Classifications: J60, J71, M12

Keywords: Executives; Mobility; Minorities; Promotions; Demotions; Exit.

* The author's affiliation is Surrey Business School, University of Surrey, UK. E-mail: p.guest@surrey.ac.uk. 


\section{Introduction}

The presence of minority groups within the executive ranks of corporate America has increased significantly over the last three decades. In 1979, of the 1,708 senior executives at Fortune 1000 firms, there were three African Americans, two Asians, two Hispanics, and eight females (Jones, 1986). By 2010, of the 2,682 executives at S\&P 1500 firms, there are 183 ethnic minority executives (comprising 32 African Americans, 106 Asians, and 45 Hispanics) and 122 females. Although these groups make up a disproportionately small number of executives relative to the US workforce, they represent an important subset of executives in which there is a strong media and political interest (Menendez 2010). ${ }^{1}$

Race, ethnicity and gender are important personal attributes that could impact the way in which executives are treated and behave. The economics literature suggests that decision makers may be prejudiced against minority executives (Becker 1971) or apply statistically discriminative rules (Phelps 1972; Arrow 1973). Theories in social psychology suggest that minorities may be disadvantaged by race or gender based stereotyping (Brenner et al. 1989), attribution biased errors (Hewstone 1990), or being singled out as a token (Kanter 1977). Such discrimination may be unintentional at both the individual and corporate level. Alternatively, it is possible that minority executives are advantaged by firms that wish to promote diversity. In terms of behavior, minority executives may have different preferences and behavioral traits to Caucasian males, with regard for example, to risk and competition.

These differences in the treatment and behavior of minority executives have potentially wide ranging consequences. ${ }^{2}$ Our interest here is in labor market outcomes for these executives.

\footnotetext{
${ }^{1}$ Placing these figures in a global context is difficult because comparable data on executives for other countries is not publicly available. However, a recent study for the UK shows that for FTSE 100 firms, 10.5 percent of executive directors are female and 4.8 percent are from ethnic minorities (Green Park, 2014).

${ }^{2}$ For example, Park and Westphal (2013) find that executives exhibit negative bias in their appraisal of minority CEOs, whilst Huang and Kisgen (2013) find that corporate investment and financial decisions made by female led firms appear less confident than those by male led firms.
} 
Whilst recent research has examined the compensation (Bertrand and Hallock 2001; MunozBullon 2010) and mobility (Gayle et al. 2012) of female executives, no study has examined these outcomes for ethnic minority executives. In this paper we therefore consider whether mobility outcomes for executives, in particular promotion, demotion and exit, differ by race, ethnicity, and gender. Establishing this is important, and may for example shed light on the widely held perception that the low representation of minority executives is due to differential mobility (Federal Glass Ceiling Commission 1995; Menendez 2010).

Our key original contribution is the examination of mobility outcomes for ethnic minorities at the executive level, on which we provide the first large sample evidence. We also contribute to the literature on the mobility of female executives, which to date for the US has only been examined by Gayle et al. (2012). Our work is most closely related to this and prior empirical studies that examine the impact of race, ethnicity, and gender on mobility outcomes at lower levels of the firm hierarchy. As with previous studies, our data reveals mobility outcomes only, and not the career aspirations of sample executives. Although promotion is probably a positive outcome for promoted executives who we presume are mostly seeking it, the absence of promotion for other executives cannot be assumed to be a negative (Pruden 1973). Similarly, we cannot assume that demotion or firm exit is a negative for the executive concerned. Although discrimination may be the cause of these outcomes, so too could unobservable executive characteristics (e.g., preferences and ability) that differ along racial and gender lines. Although it can be argued that executives are a relatively homogenous group compared to lower rank employees (Bertrand and Hallock 2001), such racial and gender differences (and their impact on mobility) could be significant. As such, racial or gender differences in executive mobility outcomes are not direct tests of discrimination.

With these limitations in mind, our objective is to establish whether any robust patterns emerge in the data. Our findings show that minority executives as a whole experience lower 
promotion rates, higher demotion rates, and higher exit rates than Caucasian males. These differences are driven by female and African American executives. Female executives have lower promotion rates and higher exit rates than men, whilst African American executives have lower promotion rates, higher demotion rates, and higher exit rates than whites. Asian and Hispanic executives in contrast do not experience different outcomes to Caucasians. If these mobility patterns were the result of discrimination or bias, they could be diminished by minority leadership. However, we find no evidence of this.

The paper proceeds as follows: the next section reviews related literature; the data section describes the data; the empirical results section presents the findings; the final section concludes.

\section{Related Literature}

\section{Theoretical Literature on Labor Discrimination and Bias}

Separate literatures in economics and social psychology provide theories on how the mobility of minority executives could be impacted by discrimination and bias.

Economic theories can be broadly categorized into two main types. Firstly, decision makers may be prejudiced and have a taste based preference to minimize interaction with minority employees (Becker 1971). The board of directors is responsible for making mobility decisions on executives, and to the extent that it is predominantly Caucasian and male, may be biased towards ethnic minorities and females. Secondly, decision makers may face asymmetric information about employee ability and use race or gender to statistically discriminate (Phelps 1972; Arrow 1973). With regard to whether statistical discrimination will hold at the executive level, the predictions of these models are mixed, depending on the nature of the inference and 
the information required for promotion decisions. Discrimination is supported by the models of Lazear and Rosen (1990) and Smith et al. (2013), but not Fryer (2007) or Bjerk (2008). ${ }^{3}$

Social psychology theories are more unanimous in predicting that minority executives will be subject to bias. Firstly, studies show that business leaders are perceived as exhibiting characteristics that are more closely correlated with the characteristics of Caucasian males than females (Brenner at al. 1989; Koenig et al. 2011) or ethnic minorities (Chung-Herrera and Lankau 2005; Rosette et al. 2008). Female and ethnic minorities may therefore be perceived to lack the characteristics of successful business leaders, and consequently be discriminated against. Such perceptions may also be held by minorities themselves, potentially deterring them from applying for top positions. Secondly, minorities may be subject to attribution bias, whereby relative to Caucasian males they are attributed insufficient recognition for outperformance and excess recognition for underperformance. This could occur because of negative stereotyping or because minorities are perceived as an 'out-group' by the 'in-group' of Caucasian males (Greenhaus and Parasuraman 1993; Hewstone 1990). Thirdly, the theory of tokenism (Kanter 1977) suggests that because they comprise a small proportion of executives, minorities are subject to greater visibility, higher pressure to perform, and isolation. The result could be a deliberate attempt to not outperform the majority, avoidance of promotion which would bring additional visibility, and higher turnover (Kanter 1977).

\section{Differences in Executive Preferences and Ability by Race and Gender}

\footnotetext{
${ }^{3}$ Lazear and Rosen (1990) suggest that women are superior to men in non-market work, resulting in a higher probability of voluntary turnover for women, and hence a lower probability of promotion. At higher ranks, promotion rates will differ by gender but less so due to the value of non-market work being lower than wages. Fryer (2007) predicts that minorities will be held to a more exacting standard at initial hiring, which lowers their probability of being hired but increases their probability of subsequent promotion. Bjerk (2008) predicts that discrimination in promotion occurs at lower levels due to signaling differences between minority and majority groups, but not at executive levels where promotion is based on task completion only.
} 
Minority executives are unlikely to be a random sample that differ from Caucasian males in terms of race and gender only. Specifically, it is possible that racial and gender differences in preferences and abilities could result in differences in mobility.

Research shows that females are more risk averse and less competitive than males (Croson and Gneezy 2009; Bertrand 2010). There is also evidence that African Americans are more risk averse than whites, whilst Hispanics do not differ (Sahm 2007). As such, female and African Americans may be reluctant to take on the risk associated with higher executive positions (Smith et al. 2013). Females could have greater family commitments resulting in a preference to avoid long work hours, promotion to the highest executive positions, and geographical relocation (Bielby and Bielby 1992). Such commitments may also lead to higher turnover. Finally, minority executive behavior may differ due to being a highly visible minority.

The ability of minority executives to meet the performance requirements for top executive positions will depend on general and firm-specific skills, combined with the effort with which these skills are applied. These factors may differ from Caucasian males. Firstly, the processes that have generated the minority and non-minority executives may differ. If minorities have been discriminated against and faced higher hurdles, they could be an exceptional group with above average ability and thus a higher probability of subsequent promotion. Alternatively, if they have been promoted through affirmative action policies they could be of lower ability, with a subsequent lower likelihood of promotion. ${ }^{4}$ Secondly, minority executives may have different functional experience which is less valuable for firm leadership positions. For example, Collins (1997) finds that African American executives often hold racialized positions, whilst Zweigenhaft and Domhoff (2011) show that female and African American executives are more likely to work in public relations, human resources and general counsel. Thirdly,

\footnotetext{
${ }^{4}$ Our review of the empirical literature suggests that neither scenario occurs in the aggregate for lower level employees. However, this does not rule out the possibility that it occurs for executives.
} 
Zweigenhaft and Domhoff (2011) show that whilst the majority of female, Hispanic and Asian executives come from the upper and upper middle class (as do white male executives), African American executives come from middle or working class backgrounds. This lower social origin may result in lower tacit knowledge for African Americans (Hansen 2001). Finally, since social networks tend to be gender and race based, white male executives may have a wider executive network (McDonald et al. 2009) which could disadvantage minorities since such networks increase the executive's value to her own firm (Engelberg et al. 2013) and hence probability of promotion (McDonald et al. 2009).

\section{Empirical Literature on Mobility Outcomes by Race and Gender}

The empirical literature on racial and gender differences in promotions has produced mixed results. Studies that combine all ethnic minority employees together report a lower probability of promotion (Paulin and Mellor 1996; Francesconi 2001; Yap and Conrad 2009). For African American employees, some studies find the probability of promotion is lower than for whites (McCue 1996; Maume 1999; Pergamit and Veum 1999; James 2000; Elvira and Zatzick 2002; Wilson and Maume 2013), whilst others find it is higher (Shenhav 1992; De Varo 2006; Blau and Devaro 2007; Giuliano et al. 2011). For Hispanic employees, Wilson and Maume (2013) find a lower probability of promotion compared to whites, other studies find a similar probability (Pergamit and Veum 1999; Elvira and Zatzick 2002; Blau and DeVaro 2007) and Giuliano et al. (2011) find a higher probability. For Asians, Elvira and Zatzick (2002) find a similar probability of promotion to whites whilst Giuliano et al. (2011) find a higher probability. For gender differences, some studies (Olson and Becker 1983; Cannings 1988; McCue 1996; Lyness and Judiesch 1999; Pergamit and Veum 1999; Lyness and Schrader 2006; Pekkarinen and Vartiainen 2006; Blau and Devaro 2007; Smith et al. 2013; Kunze and Miller 2014) find women are less likely to be promoted than men, others find a similar likelihood (Paulin and Mellor 1996; James 2000; Booth et al. 2003; Yap and Conrad 2009; Giuliano et al. 
2011), whilst others find a higher likelihood (Shenhav 1992; Gayle et al. 2012). Whilst there is an extensive empirical literature on promotions, the only empirical study on demotions is Gayle et al. (2012) who find no gender differences.

Empirical studies on turnover by race and gender tend to distinguish between involuntary (layoffs and dismissals) and voluntary turnover. With regard to involuntary turnover, there is some evidence that African Americans and Hispanics are more likely to be laid off (Elvira and Zatzick 2002) and dismissed (Giuliano et al. 2011). For Asians, the probability of either is similar to whites (Elvira and Zatzick 2002; Giuliano et al. 2011). For females, there is evidence of a higher probability of layoff (Elvira and Zatzick 2002) and dismissal (Becker-Blease et al. 2010). The evidence on voluntary turnover by race is mixed. Sicherman (1996) finds a higher probability for African Americans, but Hom et al. (2008) find no difference and Giuliano et al. (2011) find a lower probability. Hispanic employees face a similar probability of quitting (Giuliano et al. 2011; Hom et al. 2008), whilst for Asians, the findings are mixed with Giuliano et al. (2011) finding a higher rate and Hom et al. (2008) finding no difference. Females face a higher probability of voluntary turnover than males (Sicherman 1996; Hom et al. 2008; BeckerBlease et al. 2010), which is more likely to occur for personal family reasons (Sicherman 1996). Overall turnover is also higher for females than males (Krishnan 2009; Gayle et al. 2012).

In summary, no robust pattern emerges from the empirical literature on promotions in terms of racial and gender differences. However, African Americans and Hispanics experience higher involuntary turnover, whilst females experience higher involuntary and voluntary turnover.

Data

Mobility of Executives 
Our sample of executives is drawn from Execucomp. In order to identify promotions and demotions we follow the approach in Baker et al. (1994) and Gayle at al. (2012) in constructing a hierarchal structure based on the movement of executives across different occupational titles.

Of the 218,128 executive year observations over 1992-2011, occupational title is available for 171,598 using the Execucomp variables TITLEANN, CEOANN, and CFOANN. TITLEANN reports occupational titles which we check by hand, supplementing with CEOANN and CFOANN which identify the CEO and CFO respectively. We identify 13 titles that occur at least one thousand times each (individually or in conjunction with another). ${ }^{5}$ 14,291 observations cannot be classified as any of the 13 titles, which we refer to as 'Other executive of the company'. We classify each executive-year according to one or more of these 14 titles, and identify which of these 14 titles (or combination of) occurs at least one thousand times. This results in 26 titles, shown in Table 1. There remain 7,214 observations (one of the 14 titles or combination of) that do not occur one thousand times, which we deal with below.

\section{INSERT TABLE 1 HERE}

We construct an executive hierarchy based on the movement of executives across these 26 titles. We exclude all observations for which the executive's title is not available in the next annual period, reducing the sample from 171,598 to 125,589 observations. We exclude for the purposes of examining movements the 7,214 observations described above, giving a sample of 118,375 movements. In examining movements we include job transitions both within and between firms. We rank the 26 titles using the method of Gayle at al. (2012), whereby title Y ranks above title $\mathrm{X}$ if the probability of moving from $\mathrm{X}$ to $\mathrm{Y}$ is greater than the probability of moving from $\mathrm{Y}$ to $\mathrm{X}$. Furthermore, if title $\mathrm{Z}$ ranks above $\mathrm{Y}$ then we assume that it also ranks

\footnotetext{
${ }^{5}$ These titles (number) are as follows: CEO of the company $(36,410)$; Chairman of the Board $(24,086)$; Vice chair of the company (4,139); President of the company $(29,426)$; Chief operating officer of the company $(11,466)$; Executive vice president of the company $(39,547)$; Senior vice president of the company $(31,227)$; Vice president of the company (25,040); Chief financial officer of the company (27,930); Chief executive officer of a subsidiary/region (4,436); Chairman of a subsidiary/region (1,263); President of a subsidiary/region $(17,268)$; and Chief operating officer of a subsidiary/region $(1,859)$.
} 
above X. Applying this rule, seven ranks emerge clearly from the 118,375 movements, shown in the transition probability matrix for all 26 titles in Table 2, and in column (1) of Table 1.

\section{INSERT TABLE 2 HERE}

Next, we manually allocate the 7,214 observations described above into one of the 26 groups. The final transition probability matrix for all seven ranks for the 125,589 observations is shown in Table 3. We define promotion as where an executive increases her rank in the next period, and is not defined for rank 1 executives. We define demotion as where an executive decreases her rank in the next period, and is not defined for rank 7 executives. Of the 125,589 observations, we define 10,778 as promotions and 3,933 as demotions.

\section{INSERT TABLE 3 HERE}

We allow promotions and demotions to occur both within and between firms, as do previous studies (Gayle et al. 2012). Only a small proportion of sample observations $(1,156)$ involve inter-firm movements, and are associated with a high likelihood of either upward (529) or downward (253) mobility. The vast majority of sample promotions (95 percent) and demotions (94 percent) are within rather than between firms. In our analysis, we control for inter- and intra-firm mobility and check the robustness of our findings to this distinction.

We define exit as where an executive leaves Execucomp in the next period and is missing for the three subsequent years, similar to Gayle et al. (2012). Of the 171,598 observations, we exclude the last three years of the sample period (2009-2011) and observations for which the executive's firm is subsequently no longer available on Execucomp. This generates a sample of 135,804 observations for the analysis of exit, 21,005 of which are classified as preceding exit, suggesting that 16 percent of executives exit on average in each year.

\section{Minority Status of Executives}

To identify the gender of the Execucomp executives, we use the Execucomp variable 'GENDER', which is available for all Execucomp observations. 
To establish the racial identity of executives, we start with the Riskmetrics/IRRC database, which reports the race of board directors (executive and outside directors) on S\&P 1500 firms as either Caucasian, African American, Asian, Hispanic or Native American. We clean this database to correct inaccuracies in the IRRC numerical codes assigned to each director. ${ }^{6}$ This results in 32,612 unique directors over 1996-2011, of which 1,680 are minorities, 18,215 are Caucasian, and 12,717 are of unknown race. Due to inaccuracies with the IRRC identification of race $^{7}$ we manually check the race of the 1,680 minority directors.

To do so, we employ several published lists of minority directors/executives and crosscheck these individuals on IRRC. We identify 684 IRRC directors as minorities in this way ${ }^{8}$ (605 of whom were originally identified as minorities by IRRC). Of the remaining 1,075 IRRC minority directors, we verify the minority status of 371 using online biographies, 178 using online photos, and 451 using names (clear Hispanic or Asian name consistent with IRRC classification). 62 of the 1,075 are concluded to be Caucasian using online biographies and photos. For the 13 remaining directors we are unable to verify their race and therefore accept the IRRC classification. We therefore have 19,933 directors with verified racial identification comprising 18,235 Caucasian and 1,698 minorities, the latter consisting of 682 African

\footnotetext{
${ }^{6}$ Of the 34,938 unique codes there are 869 directors which have more than one unique code, and 1,209 unique codes for which there is more than one director. Directors are identified using name, CUSIP, and date of birth.

${ }^{7}$ For example, 343 of these 1,680 directors have inconsistent racial classification over time.

8328 African American [Executive Leadership Council (2004; 2008), Zweigenhaft and Domhoff (2011), http://www.blackenterprise.com/mag/power-in-the-boardroom/, http://www.blackenterprise.com/be-lists/the100-most-powerful-executives-in-corporate-america/4/, http://www.blackentrepreneurprofile.com/fortune-500ceos/, http://www.thefreelibrary.com/America's+most+powerful+Black+executives\%3A+B.E.+selects+40+allstars...-a013506897, http://savoynetwork.com/category/the-list/.], 168 Asian [Committee of 100 (2004; 2007), Leadership Education for Asian Pacifics (2011), Zweigenhaft and Domhoff (2011), http://www.china4us.com/SinoCEO.htm, and http://www.88yp.com/Executives.htm.], and 189 Hispanic [Hispanic Business Com (2002, 2004, 2005), Hispanic Association on Corporate Responsibility (2007), Zweigenhaft and Domhoff (2011), http://www.hispanicbusiness.com/branded/2013/elite/boardroom_elite_bios.asp, http://www.hispanicbusiness.com/2009/1/28/2009_boardroom_elite_complete_list.htm]. These website links were accessed in December 2012.
} 
Americans, 616 Asians, 398 Hispanics, and two Native Americans. ${ }^{9}$ From the published lists, we identify a further 56 minority executives that are not on IRRC.

We match these 19,989 individuals with Execucomp executives using names and firm CUSIPs, resulting in a sample of 8,126 executives. Of these executives, 392 are female and 432 are ethnic minorities, comprising 114 African Americans, 211 Asians, and 107 Hispanics. Thus in total there are 792 minority executives accounting for 9.8 percent of sample executives. There are 68,962 executive-firm-year observations for which race and gender is known. This sample of executives and observations is displayed in Panel A of Table 4.

\section{INSERT TABLE 4 HERE}

\section{Control Variables}

In our regression model, we control for executive age, tenure, educational attainment, occupation, inter-firm mobility, firm characteristics and industry.

We collect the age of executives from Execucomp (variable 'AGE'). Company tenure (variable 'JOINED_CO') is not reported comprehensively on Execucomp. We therefore also collect the years of credited service under the company's pension plan (variable 'RET_YRS'), tenure as CEO (using the variable 'BECAME CEO'), and company tenure [variable 'Time (Yrs.) in Company'] from the BoardEx database. We employ the highest figure from these four sources as our company tenure variable.

We collect educational data from BoardEx (variable 'Education'), and include three dummy variables (bachelor's, master's, and $\mathrm{PhD}$ ) to measure higher levels of educational attainment as follows; Bachelor's is set equal to one if the executive has an undergraduate degree, zero if not; Master's is set equal to one if the executive has a postgraduate master's degree (including MBA), zero if not; $\mathrm{PhD}$ is set equal to one if the executive has a $\mathrm{PhD}$, zero if not.

\footnotetext{
${ }^{9}$ Identification of directors' race for earlier IRRC years for which race is not reported is backfilled.
} 
Minority executives may tend to work in functional areas for which promotion is less likely. For example, female and African American executives are more likely to hold positions in the areas of public relations, human resources and general counsel (Zweigenhaft and Domhoff 2011). Such functions do not directly contribute to revenues and profits, and do not feed into the higher positions such as $\mathrm{COO}$ which in turn leads to CEO. We employ the Execucomp variable 'TITLEANN' to identify all executives working in these areas, for which the variable communications, HR, or legal is a dummy variable set equal to one.

We control for inter-firm transitions by including a dummy variable, firm change, which is set equal to one if an executive moves to another firm in the next period, zero otherwise. We employ firm size and firm performance as control variables. Total assets (Compustat data item 6) is our measure of firm size, and converted to 2011 US dollars using the consumer price index. The variable stock return, is taken from CRSP, and is the annual stock return over the fiscal year. Both variables are winsorized at the one percent level. To control for the possibility that minority executives could be located in industries with different mobility patterns, we include industry fixed effects using two digit SIC codes.

Data availability for these control variables reduces the sample as shown in Panel B of Table 4. Our analysis of promotion and demotion requires data availability on rank for the next period, which reduces our sample further as shown in Panel $\mathrm{C}$ of Table 4.

\section{Empirical Results}

\section{Executive Characteristics}

The sample averages for rank, education, age, tenure and functional role are reported in Table 5, along with those for Caucasian males and minorities. Minorities are less likely to be in ranks 1 or 2 , equally likely to be in rank 3, and more likely to be in ranks 4 through 7 . Minorities achieve a higher education level than Caucasian males, being more likely to hold a 
master's degree and $\mathrm{PhD}$. Minorities are on average three years younger with three years less firm tenure. The age difference is driven partly by minorities' younger entry into the executive ranks. For their first Execucomp observation (excluding 1992, the first year of Execucomp data), the average age is 48 for minorities and 50 for Caucasian males (whilst firm tenure is 8 years for both), suggesting minorities may have been promoted faster. The lower average age for minorities is also caused, as is tenure, by their lower age (53 compared to 58) and tenure (15 compared to 20) at exit. We calculate work experience as current age minus assumed age of finishing education (18 if no undergraduate degree; 21 for undergraduate degree; 22 for master's degree; 27 for PhD). Minorities have less experience (29 years) than Caucasian males (32 years). Finally, a higher proportion of minorities work in communications, human resources or law.

\section{INSERT TABLE 5 HERE}

Separating minorities into females and ethnic minorities, the patterns hold for both except in the case of education where females are no more likely to hold a master's degree or $\mathrm{PhD}$ than Caucasian males. Splitting ethnic minorities into African Americans, Asians and Hispanics, reveals some differences. Whilst the rank and age differences hold, Hispanics do not have lower tenure than Caucasian males, and only Asians are more likely to hold a PhD.

In summary, minorities as a whole differ from Caucasian males in terms of rank, education, age, tenure, experience and functional area.

\section{Univariate Analysis of Promotion, Demotion and Exit}

Table 6 reports the univariate analysis of the three mobility events. Panel A shows that there are no significant differences in promotion likelihood between Caucasian males (9.9 percent) and minorities (9.6 percent). Similarly, the likelihood of promotion for females (9.2 percent) and ethnic minorities (10.1 percent) does not differ significantly from Caucasian males. 
Separating ethnic minorities into African Americans (9.8 percent), Asians (9.6 percent), and Hispanics (11.3 percent) also reveals no significant differences.

\section{INSERT TABLE 6 HERE}

Panel B shows that minorities have significantly higher demotion rates (3.7 percent) than Caucasian males (2.2 percent). The demotion probability is higher for females (4.2 percent) than it is for ethnic minorities (3.3 percent) but both are significantly different from Caucasian males. Within the ethnic minority groups, only African Americans face a significantly higher probability (5.9 percent) compared to Caucasian males. In contrast, the probabilities for Asians (2.8 percent) and Hispanics (2.6 percent) are no different.

Panel $\mathrm{C}$ shows that the probability of exit is 6.1 percent for Caucasian males, which is significantly lower than the probability of 7.3 percent for minorities. Females face an 8 percent probability of exit, significantly higher than Caucasian males. Ethnic minorities face a 6.9 percent probability which is not significantly higher. African Americans face a significantly higher probability (11 percent) than Caucasian males whilst Asians and Hispanics do not.

In summary, we find no significant differences in terms of promotion, but significantly higher probability of demotion and exit for female and African American executives.

\section{Multivariate Analysis of Promotion}

To examine these mobility events within a multivariate regression framework, we employ a binary logit model. The multivariate analysis of promotion, shown in Table 7, produces different results from the univariate analysis. From column (1), the estimated coefficient for the minority dummy variable is a significant -0.338 , implying that minority groups have a 29 percent lower probability of promotion than Caucasian males. This impact is very much driven by females as shown in column (2), where the coefficient for female is a significant -0.541 , implying a 42 percent lower probability. In contrast, the coefficient for ethnic is an insignificant -0.112 and therefore ethnic minorities as a whole do not have a significantly lower probability. 
However, column (3) shows that African Americans have a significantly lower probability of promotion whilst Hispanics and Asians do not. The coefficient for African Americans of - 0.431 implies that African Americans face a 35 percent lower probability. The lower probability of promotion for female and African Americans is economically as well as statistically significant.

\section{INSERT TABLE 7 HERE}

In terms of control variables, the probability of promotion decreases linearly with rank, except for rank 3 which has a higher probability than rank 4. Having a bachelor's degree is significantly positively associated with promotion, whilst a master's degree or $\mathrm{PhD}$ is not. Age has a negative but diminishing impact on promotion, whilst tenure is positively correlated. The coefficient for the communications, HR, or legal variable is significantly negative, thus those working in these areas are less likely to be promoted. The coefficient for firm change is significantly positive, thus for executives that move firm the probability of promotion increases significantly. Firm size does not have a significant impact on promotion probability. Firms with lower share returns have a higher probability of promotion, possibly reflecting higher executive exit (and hence opportunity for promotion) in underperforming firms.

Minorities are often described as facing a glass ceiling, whereby progression becomes less likely beyond a certain rank. To examine this, we run the promotion regression separately for ranks two through seven. The results, reported in a separate Appendix (Table A1), ${ }^{10}$ show that the negative effect for minorities is greatest at ranks 2, 4 and 7, yet at its smallest and insignificant at rank 3 . There is therefore no clear evidence of a glass ceiling for one particular rank. To test further for significant differences by rank, we interact the minority dummy variable with the rank dummy variables. The results, reported in the Appendix (Table A2), show the coefficients for these interactive variables to be insignificant. Therefore, the

\footnotetext{
10 The Appendix is available from the author upon request.
} 
probability of promotion by rank for minorities does not differ from that of Caucasians, and hence there is no evidence of a glass ceiling.

Our conclusion that female executives face a lower probability of promotion than male executives differs from Gayle et al.'s (2012) conclusion that females face a higher probability. However, Gayle et al. base their conclusion on a select sample of executives which are included in the publication Marquis Who's Who, which by definition are a select group of (probably) the most highly successful executives. In an earlier version of their paper (Gayle et al. 2009), Gayle et al. also present results for a larger comprehensive sample and find that the probability of promotion for females is significantly lower than that for males. Gayle et al. prefer the use of the smaller Who's Who sample because it enables them to control for age and education. However, not controlling for these factors results in an upward bias on the probability of promotion for females, and it follows that for their larger sample, the lower probability for females would likely be lower still with the inclusion of these variables.

\section{Multivariate Analysis of Demotion}

The regression results for demotion are shown in Table 8. Consistent with the univariate analysis, minority status is associated with a significantly higher probability of demotion. Column (1) shows that the coefficient for the minority variable is a significant 0.275 implying a 32 percent higher probability of demotion. From column (2), the coefficient for the female dummy variable is a statistically insignificant 0.241 , whilst the coefficient for the ethnic dummy variable is 0.274 and significant at the ten percent level. Column (3) shows that the coefficient for African American is statistically significant with a value of 0.555 . This implies a probability of demotion that is some 73 percent higher than Caucasians. In contrast, neither Hispanics nor Asians experience a different probability of demotion to Caucasians.

\section{INSERT TABLE 8 HERE}


Considering the control variables, chairmen (rank 1) face a higher probability of demotion, whilst CEOs (rank 2) and those just below them (rank 3) face a lower probability. Executives with a master's degree face a lower probability of demotion, whilst those working for larger firms face a higher probability. Executive age, tenure, and functional role do not impact demotion likelihood. Our finding for the impact of gender, positive but insignificant, is consistent with Gayle et al. (2012). In summary, minorities as a whole face a higher probability of demotion, and this effect is largely driven by African American executives.

\section{Multivariate Analysis of Exit}

Table 9 reports the binary logit regressions for exit. Column (1) shows that the coefficient for minority is a significant 0.311 , implying that minorities are 37 percent more likely to exit than Caucasian males. Column (2) shows that this effect is driven by females, the coefficient for female being 0.35 and implying a 42 percent higher probability of exit. The coefficient for ethnic minorities is an insignificant 0.079. Column (3) shows that there is a notable difference between African Americans and other ethnic minorities. The coefficient for the former is 0.438 and highly significant, rendering African Americans 55 percent more likely to exit than Caucasians. In contrast, Asian and Hispanic executives do not differ from Caucasians in exit probability. Higher rank (except the chairman), tenure, a $\mathrm{PhD}$, and share return are associated with a lower probability, whilst age and firm size are associated with a higher probability.

\section{INSERT TABLE 9 HERE}

One possibility is that minorities are punished more for firm underperformance, and are therefore more likely to exit when performance is poor. To test this, we interact the minority dummy variable with the share return variable. The results, reported in the Appendix (Table A3), show that exit for minorities is not more closely linked to performance than for Caucasian males. Since we expect the link between performance and exit to be strongest for CEOs (rank 2), we include an interaction term for rank 2 and share return, and also interact the minority 
dummy with this variable. Exit for rank 2 executives is more highly correlated with share return than other ranks, however this link is not stronger for minorities.

Prior promotions and demotions may impact the likelihood of exit. Promoted employees may be more attached to the firm and less likely to leave (Carson et al. 1994), whilst demoted employees may be the opposite. Since minorities experience lower promotion and higher demotion, we would a priori expect a higher likelihood of exit and we therefore test whether their higher exit propensity is independent of prior promotion and demotion. We include as explanatory variables the promotion and demotion variables for the current year. The results, reported in the Appendix (Table A4), show that promotion has a significantly negative impact on exit and demotion has an insignificantly positive impact. Minority status continues to be significantly positively correlated with exit. However, the coefficient for African American is statistically insignificant. Since this analysis employs a reduced sample size (due to prior year rank being required), we rerun our original model on this reduced sample. The coefficients for the minority dummy variables are very similar in magnitude and significance, indicating that any difference from the Table 9 results is due to the smaller sample rather than the inclusion of promotion and demotion. This makes it difficult to draw a firm conclusion on African Americans, but we can conclude that the higher exit for minorities as a whole (and females) holds after controlling for promotion and demotion.

\section{Robustness Tests}

In this section we conduct additional tests to check the robustness of our key findings.

Firstly, we consider intra- and inter-firm mobility. For our sample of 37,681 observations (Panel C, Table 4), there are 457 inter-firm movements consisting of 237 promotions, 85 demotions, and 135 same rank movements. For minorities, there are 45 inter-firm movements, consisting of 23 promotions, 14 demotions, and 8 same rank movements. In the above analysis, we controlled for the possibility that minorities have a different likelihood of inter-firm 
movement by including the dummy variable, firm change. We now examine whether this is the case, employing this variable as the dependent variable in a logit regression. The results, reported in the Appendix (Table A5), show that the coefficient for the minority variable is insignificant and therefore inter-firm mobility is not correlated with minority status. Next, we examine how our main findings differ if we exclude all 457 inter-firm transitions. The results for internal promotion show that the coefficient for minority is of the same magnitude and significance. However, for internal demotion the coefficient for minority is smaller $(0.192$ rather than 0.275 ) than in Table 8 and now statistically insignificant. Therefore our finding of higher demotion for minorities does not hold for internal transitions. We also separately examine inter-firm promotions and demotions, although as noted above the number of external transitions involving minorities is low. The coefficient for minority in the external promotion regression is of a similar magnitude to that for the internal promotion regression although statistically insignificant. For the external demotion regression, the coefficient for minority is significantly negative, suggesting that minorities that change firms are more likely to lower their rank. This is consistent with biased stereotyping (lower positions) occurring where knowledge of the individual is lower, namely the external labor market.

As noted above, our finding that females face a lower likelihood of promotion differs from Gayle et al. (2012). We examine the robustness of this finding by utilizing a larger sample for which all variables are available except ethnicity. This sample, described in Table 4 (Panel C) consists of up to 76,184 observations. The results, reported in the Appendix (Table A6), are consistent with those in Tables 7-9. The coefficient for gender is significantly negative in the promotion regression, insignificantly positive in the demotion regression, and significantly positive in the exit regression.

We examine how robust our findings are over time and whether the relation between minority status and mobility has changed, by employing a dummy variable, post-2001, set 
equal to one for years 2002-2010 and zero for 1992-2001. We include this variable and it's interaction with the minority variable to test whether the impact of minority status differs across time. The results, reported in the Appendix (Table A7), show that the coefficient for the interaction variable is statistically insignificant in the demotion and exit regressions, and significantly negative at the ten percent level in the promotion regression. There is therefore no strong evidence of a changing relation over time.

Finally, to control for the possibility that minorities are located in firms that are correlated with lower promotion, higher demotion, or higher exit, we employ a firm fixed effects model. The results, reported in the Appendix (Table A8), are consistent with those in Tables 7-9 and thus our key findings are robust to the potential problem of omitted firm fixed effects.

\section{The Impact of Minority Leadership}

If the mobility patterns are due to discrimination, this may diminish where minorities occupy firm leadership positions. Prior evidence on such effects is mixed. For example, Matsa and Miller (2011) show that the proportion of female directors leads to a higher number of female executives, whilst other gender studies find no such impacts (Blau and DeVaro 2007; Smith et al. 2013). A limitation here is that our sample of mobility events for minorities is small, making it difficult to look within and find statistically reliable correlations.

Firstly, for 20,188 non-CEO sample observations, we identify 946 where the firm CEO (rank 2) is a minority. We include a dummy variable set equal to one for these observations and interact it with the minority variable. The results, reported in the Appendix (Table A9), show that the interaction term is statistically insignificant, whilst the coefficient for minority retains the same sign and significance as in Tables 7-9. Secondly, we identify the ethnicity and gender of all board directors for 17,412 sample observations, and for this subsample calculate the proportion of minority directors to total directors (excluding the sample executive from the numerator and denominator if he/she is also a director). We include this variable and interact 
it with the minority variable. The coefficients, reported in the Appendix (Table A9), for both variables are insignificant. The coefficient for minority continues to be of the same sign and significance in the promotion and exit regressions, although it loses its statistical significance in the demotion regression. The latter appears to be the result of the smaller sample employed since the coefficient for the interaction term is positive.

In summary, the presence of minorities in leadership positions does not impact the mobility of minority executives. This does not imply that discrimination is not a factor in the mobility patterns observed. Minority CEOs or board members may not wish or be able to eradicate taste based or statistical discrimination, whilst biased stereotyping and attribution bias may occur without their conscious knowledge or intent.

\section{Conclusion}

We have shown that minority executives experience different outcomes in mobility compared to Caucasian male executives. Minorities experience a lower probability of promotion, a higher probability of demotion, and a higher probability of exit. These differences are statistically robust and economically important, being 29, 32, and 37 percent respectively. This pattern differs across minority groups, being driven by female and African American executives. Compared to male executives, females face a lower probability of promotion and a higher probability of exit. Compared to Caucasian executives, African Americans face a lower probability of promotion, and a higher probability of demotion and exit. In contrast, Asian and Hispanics do not experience differences in mobility outcomes compared to Caucasians.

Our primary objective has been to identify whether executive mobility outcomes differ by race and gender. We contribute to the literature by showing that race and gender have important implications for labor market outcomes at the highest level of corporate America. A limitation of our analysis is that we do not show why these differences in mobility occur, and as such, 
our interpretation and understanding of these outcomes is limited. Our results are consistent with multiple explanations, which our empirical approach does not enable us to tease apart.

The mobility outcomes of females and African Americans are consistent with several theories of discrimination and/or bias. Boards of directors could have a taste based preference against working with female and African American executives, statistically discriminate against them, be biased by stereotyping or make attribution bias errors. On the question of why African Americans would be discriminated against but not Hispanics and Asians, such bias is likely most prevalent towards African Americans since they face more difficult barriers in terms of stereotypes, physical difference, and a history of slavery and segregation.

However, the outcomes are also consistent with racial and gender differences in preferences or ability. For African Americans, lower promotion could reflect a preference not to apply for higher positions due to lower risk aversion. It is not clear however, how lower risk aversion could lead to the higher rate of demotion. Alternatively, our sample of African Americans could have lower ability, resulting in lower promotion, higher demotion, and higher exit. For females, lower risk aversion, lower preference for competition, or external time demands due to greater family commitments could result in higher positions not being sought. Similarly, higher exit could reflect a preference to leave voluntarily due to family commitments. Alternatively, females could on average have lower ability. Whilst this could explain lower promotion and higher exit, one would also expect to observe higher demotion, which we do not.

Distinguishing between these alternative explanations is essential to our interpretation of these outcomes. We hope that future research will attempt to do so and believe there are a number of interesting lines of enquiry. It would be interesting to know how minority executives fare in other labor market outcomes such as compensation and the interaction of compensation with mobility outcomes, how prior career paths, experience and firm specific roles differ by race and gender, and, given the high exit rate for minority executives, their subsequent career 
path and alternatives outside the firm. Finally, a potentially fruitful approach would be to interview minority executives. This could shed considerable light, particularly with regard to their preferences, on why they are less likely to be promoted, more likely to be demoted and more likely to exit the executive ranks. 


\section{REFERENCES}

Arrow, Kenneth. 1973. "The Theory of Discrimination.” In Discrimination in Labor Markets, edited by Orley Ashenfelter and Albert Rees, pp. 3-34. Princeton, NJ: Princeton University Press.

Baker, George, Michael Gibbs, and Bengt Holmstrom. 1994. "The Internal Economics of the Firm: Evidence from Personnel Data." Quarterly Journal of Economics 109(4): 881-919.

Becker, Gary S. 1971. The Economics of Discrimination. Chicago: University of Chicago Press.

Becker-Blease, John R., Susan Elkinawy, and Mark Stater. 2010. "The Impact of Gender on Voluntary and Involuntary Executive Departure.” Economic Inquiry 48(4): 1102-18.

Bertrand, Marianne, and Kevin F. Hallock. 2001. "The Gender Gap in Top Corporate Jobs.” Industrial and Labor Relations Review 55(1): 3-21.

Bertrand, Marianne. 2010. "New Perspectives on Gender." In Handbook of Labor Economics, edited by Orley Ashenfelter and David Card, pp. 1543-90. Amsterdam: Elsevier.

Bielby, William T., and Denise D. Bielby. 1992. "I Will Follow Him: Family Ties, Gender-Role Beliefs, and Reluctance to Relocate for a Better Job." American Journal of Sociology 97(5): 1241-67.

Bjerk, David. 2008. "Glass Ceilings or Sticky Floors? Statistical Discrimination in a Dynamic Model of Hiring and Promotion." Economic Journal 118(July): 961-82.

Blau, Francine D., and Jed DeVaro. 2007. "New Evidence on Gender Differences in Promotion Rates: An Empirical Analysis of a Sample of New Hires." Industrial Relations: A Journal of Economy and Society 46(3): $511-51$.

Booth, Alison L., Marco Francesconi, and Jeff Frank. 2003. "A Sticky Floors Model of Promotion, Pay, and Gender." European Economic Review 47(2): 295-322.

Brenner, O.C., Joseph Tomkiewicz, and Virginia E. Schein. 1989. "The Relationship between Sex Role Stereotypes and Requisite Management Characteristics Revisited." Academy of Management Journal 32(3): 662-69.

Cannings, Kathy. 1988. "Managerial Promotion: The Effects of Socialization, Specialization, and Gender." Industrial and Labor Relations Review 42(1): 77-88.

Carson, Paula Phillips, Kerry D. Carson, Rodger W. Griffeth, and Robert P. Steel. 1994. "Promotion and Employee Turnover: Critique, Meta-analysis, and Implications." Journal of Business and Psychology 8(4): 455-66.

Carson, Paula, P., and Kerry D. Carson. 2007. "Demystifying Demotion: A look at the Psychological and Economic Consequences on the Demotee.” Business Horizons 50(6): 455-66.

Chung-Herrera, Beth G., and Melanie J. Lankau. 2005. "Are We There Yet? An Assessment of Fit between Stereotypes of Minority Managers and the Successful-Manager Prototype." Journal of Applied Social Psychology 35(10): 2029-56.

Collins, Sharon. 1997. "Black Mobility in White Corporations: Up the Corporate Ladder but out on a Limb." Social Problems 44(1): 55-68.

Committee of 100. 2004. The Committee of 100's Asian Pacific American APA Corporate Board Report Card.

Committee of 100. 2007. 2007 Corporate Board Report Card: A Report on Directors of Asian Ethnicity on Fortune 500 Boards. 
Croson, Rachel, and Uri Gneezy. 2009. “Gender Differences in Preferences.” Journal of Economic Literature 47(2): 1-27.

DeVaro, Jed. 2006. "Internal Promotion Competitions in Firms." The RAND Journal of Economics 37(3): 52142.

Elvira, Marta M., and Christopher D. Zatzick. 2002. "Who’s Displaced First? The Role of Race in Layoff Decisions.” Industrial Relations: A Journal of Economy and Society 41(2): 329-61.

Engelberg, Joseph, Pengjie Gao, and Christopher A. Parsons. 2013. "The Price of a CEO's Rolodex.” Review of Financial Studies 26(1): 79-114.

Executive Leadership Council. 2004. 2004 Census of African Americans Serving on Boards of Directors of Fortune 500 Companies.

Executive Leadership Council. 2008. 2008 Census of African Americans Serving on Boards of Directors of Fortune 500 Companies.

Federal Glass Ceiling Commission. 1995. A Solid Investment: Making Full Use of the Nation's Human Capital. Francesconi, Marco. 2001. "Determinants and Consequences of Promotions in Britain." Oxford Bulletin of Economics and Statistics 63(3): 279-310.

Fryer, Roland G. 2007. "Belief Flipping in a Dynamic Model of Statistical Discrimination.” Journal of Public Economics 91(5-6): 1151-66.

Gayle, George-Levi, Limor Golan, and Robert A. Miller. 2009. “Are there Glass Ceilings for Female Executives?” Tepper School of Business Working Paper.

Gayle, George-Levi, Limor Golan, and Robert A. Miller. 2012. "Gender Differences in Executive Compensation and Job Mobility." Journal of Labor Economics 30(4): 829-72.

Giuliano, Laura, David I. Levine, and Jonathan Leonard. 2011. "Racial Bias in the Manager-Employee Relationship." The Journal of Human Resources 46(1): 26-52.

Greenhaus, Jeffery H., and Saroj Parasuraman. 1993. "Job Performance Attributions and Career Advancement Prospects: An Examination of Gender and Race Effects.” Organizational Behavior and Human Decision Processes 55(2): 273-97.

Green Park, 2014. The Green Park Leadership 10,000: A Review of Diversity amongst the UK's Most Influential Business Leaders. London: Green Park.

Hansen, Marianne N. 2001. "Education and Economic Rewards. Variations by Social-Class Origin and Income Measures.” European Sociological Review 17(3): 209-31.

Hewstone, Miles. 1990. “The 'Ultimate Attribution Error'? A Review of the Literature on Intergroup Causal Attribution.” European Journal of Social Psychology 20(4): 311-35.

Hispanic Association on Corporate Responsibility. 2007. Corporate Governance Study 2007.

Hispanic Business, Various editions (January/February 2002; January/February 2004; January/February 2005): (Hispanic Business Com).

Hom, Peter W., Loriann Roberson and Aimee D. Ellis. 2008. "Challenging Conventional Wisdom about who quits: Revelations from Corporate America.” Journal of Applied Psychology 93(1): 1-34.

Huang Jiekun and Darren J. Kisgen. 2013. “Gender and Corporate Finance: Are Male Executives Overconfident Relative to Female Executives?” Journal of Financial Economics 108(3): 822-39. 
James, Erika Hayes. 2000. "Race-Related Differences in Promotions and Support: Underlying Effects of Human and Social Capital." Organization Science 11(5): 493-508.

Jones, Edward W. 1986. “Black Managers: The Dream Deferred.” Harvard Business Review 64(3): 84-93.

Kanter, Rosabeth M. 1977. Men and Women of the Corporation. New York: Basic Books.

Koenig, Anne M., Alice H. Eagly, Abigail A. Mitchell, and Tiina Ristikari. 2011. “Are Leader Stereotypes Masculine? A Meta-Analysis of Three Research Paradigms.” Psychological Bulletin 137(4): 616-42.

Krishnan, Hema A. 2009. "What Causes Turnover among Women on Top Management Teams?” Journal of Business Research 62(11): 1181-86.

Kunze, Astrid, and Amalia R. Miller. 2014. "Women helping Women? Evidence from Employee-Employer Matched Data on the Private Sector.” NBER Working Paper No. 20761.

Lazear, Edward P., and Sherwin Rosen. 1990. "Male-Female Wage Differentials in Job Ladders." Journal of Labor Economics 8(1):106-23.

Leadership Education for Asian Pacifics. 2011. 2011 API Representation on Fortune 500 Boards.

Lyness, Karen S. and Christine A. Schrader. 2006. "Moving Ahead or Just Moving? An Examination of Gender Differences in Senior Corporate Management Appointments." Group \& Organization Management 31(6): 651-76.

Lyness, Karen S., and Michael K. Judiesch. 1999. "Are Women more likely to be Hired or Promoted into Management Positions?" Journal of Vocational Behavior 54(1): 158-73.

Matsa, David A., and Amalia R. Miller. 2011. "Chipping Away at the Glass Ceiling: Gender Spillovers in Corporate Leadership.” American Economic Review 101(3): 635-39.

Maume, David J. 1999. “Glass Ceilings and Glass Escalators.” Work and Occupations 26(4): 483-509.

McCue, Kristin. 1996. "Promotions and Wage Growth.” Journal of Labor Economics 14(2): 175-209.

McDonald, Steve, Nan Lin, and Dan Ao. 2009. "Networks of Opportunity: Gender, Race, and Job Leads." Social Problems 56(3): 385-402.

Menendez, Robert. 2010. Corporate Diversity Report.

Munoz-Bullon, Fernando. 2010. “Gender-compensation Differences among High-level Executives in the United States." Industrial Relations: A Journal of Economy and Society 49(3): 346-70.

Olson, Craig A., and Brian E. Becker. 1983. "Sex Discrimination in the Promotion Process.” Industrial and Labor Relations Review 36(4): 624-41.

Park, Sun Hyun, and James D. Westphal. 2013. "Social Discrimination in the Corporate Elite: How Status Affects the Propensity for Minority CEOs to Receive Blame for Low Firm Performance.” Administrative Science Quarterly 58(4): 542-86.

Paulin, Elizabeth A., and Jennifer M. Mellor. 1996. "Gender, Race, and Promotions within a Private-Sector Firm." Industrial Relations: A Journal of Economy and Society 35(2): 276-95.

Pergamit, Michael R., and Jonathan R. Veum. 1999. "What is a Promotion?” Industrial and Labor Relations Review 52(4): 581-601.

Pekkarinen, Tuomas, and Juhana Vartiainen. 2006. "Gender Differences in Promotion on a Job Ladder: Evidence from Finish Metalworkers.” Industrial and Labor Relations Review 59(2): 285-301.

Phelps, Edmund S. 1972. "The Statistical Theory of Racism and Sexism.” American Economic Review 62(4): 659-61. 
Pruden, Henry O. 1973. "The Upward Mobile, Indifferent, and Ambivalent typology of Managers.” Academy of Management Journal 16(3): 454-64.

Rosette, Ashleigh S., Geoffrey J. Leonardelli, and Katherine W. Phillips. 2008. "The White Standard: Racial Bias in Leader Categorization.” Journal of Applied Psychology 93(4): 758-77.

Sahm, Claudia R. 2007. "Stability of Risk Preference." Board of Governors of the Federal Reserve System Working Paper No. 2007-66.

Shenhav Yehouda. 1992. "The Entrance of Blacks and Women into Managerial Positions in Science and Engineering Occupations: A Longitudinal Analysis” Academy of Management Journal 35(4): 889-901.

Sicherman, Nachum. 1996. "Gender Differences in Departures from a Large Firm.” Industrial Labor Relations Review 49(3): 484-505.

Smith, Nina, Valdemar Smith, and Mette Verner. 2013. "Why are so Few Females Promoted into CEO and Vice President Positions? Danish Empirical Evidence, 1997-2007.” Industrial and Labor Relations Review 66(2): $380-408$.

Wilson George and David J. Maume. 2013. “Men’s Race-Based Mobility into Management: Analyses at the Blue Collar and White Collar Job Levels.” Research in Social Stratification and Mobility 33(September): 1-12.

Yap, Margaret, and Alison M. Konrad. 2009. "Gender and Racial Differentials in Promotions: Is there a Sticky Floor, a Mid-Level Bottleneck, or a Glass Ceiling?” Relations Industrielles / Industrial Relations 64(4): 593619.

Zweigenhaft, Richard L., and William G. Domhoff. 2011. The New CEOs: Women, African American, Latino and Asian American Leaders of Fortune 500 Companies. Maryland: Rowman and Littlefield. 
TABLE 1

EXECUTIVE TITLES AND RANKS

\begin{tabular}{|c|c|c|c|}
\hline Rank & $\begin{array}{l}\text { Order } \\
\text { within } \\
\text { rank }\end{array}$ & Code & Executive title \\
\hline 1 & a & 1 & Chairman of the board \\
\hline \multirow[t]{4}{*}{2} & a & 2 & Chairman of the board and chief executive officer of the company \\
\hline & $\mathrm{b}$ & 3 & Chairman of the board and chief executive officer and president of the company \\
\hline & c & 4 & Chief executive officer and president of the company \\
\hline & $\mathrm{d}$ & 5 & Chief executive officer of the company \\
\hline \multirow[t]{3}{*}{3} & $\mathrm{a}$ & 6 & President and chief operating officer of the company \\
\hline & a & 7 & Vice chair of the company \\
\hline & $\mathrm{b}$ & 8 & President of the company \\
\hline \multirow[t]{4}{*}{4} & $\mathrm{a}$ & 9 & Executive vice president of the company \\
\hline & $\mathrm{b}$ & 10 & Executive vice president and chief operating officer of the company \\
\hline & c & 11 & Chief operating officer of the company \\
\hline & c & 12 & Executive vice president and chief financial officer of the company \\
\hline \multirow[t]{4}{*}{5} & a & 13 & Executive vice president and other executive of the company \\
\hline & a & 14 & Executive vice president of the company and president of a subsidiary/region \\
\hline & a & 15 & Senior vice president of the company \\
\hline & $\mathrm{b}$ & 16 & Senior vice president and chief financial officer of the company \\
\hline \multirow[t]{4}{*}{6} & a & 17 & Senior vice president of the company and president of a subsidiary/region \\
\hline & a & 18 & Senior vice president and other executive of the company \\
\hline & a & 19 & Vice president of the company \\
\hline & $\mathrm{b}$ & 20 & Vice president and chief financial officer of the company \\
\hline \multirow[t]{6}{*}{7} & a & 21 & President of a subsidiary/region \\
\hline & $\mathrm{b}$ & 22 & Vice president of the company and president of a subsidiary/region \\
\hline & $\mathrm{b}$ & 23 & President and chief executive officer of a subsidiary/region \\
\hline & $b$ & 24 & Vice president and other executive of the company \\
\hline & $\mathrm{b}$ & 25 & Chief financial officer of the company \\
\hline & $\mathrm{b}$ & 26 & Other executive of the company \\
\hline
\end{tabular}

NOTES: The data are from Standard \& Poor's Execucomp database for 1992-2011. The 26 executive titles or combination of executive titles occur at least one thousand times within the dataset. The number of observations is 171,598 . 
TABLE 2

TRANSITION PROBABILITY MATRIX FOR THE 26 EXECUTIVE TITLES

\begin{tabular}{|c|c|c|c|c|c|c|c|c|c|c|c|c|c|c|c|c|c|c|c|c|c|c|c|c|c|c|c|}
\hline \multirow[t]{2}{*}{ Rank } & \multirow[b]{2}{*}{ Code } & \multirow{2}{*}{$\begin{array}{l}1 \\
1\end{array}$} & \multicolumn{4}{|l|}{2} & \multicolumn{3}{|l|}{3} & \multicolumn{4}{|l|}{4} & \multicolumn{4}{|l|}{5} & \multicolumn{4}{|l|}{6} & \multicolumn{6}{|l|}{7} \\
\hline & & & 2 & 3 & 4 & 5 & 6 & 7 & 8 & 9 & 10 & 11 & 12 & 13 & 14 & 15 & 16 & 17 & 18 & 19 & 20 & 21 & 22 & 23 & 24 & 25 & 26 \\
\hline 1 & 1 & 62 & 3 & 1 & 0 & 0 & & 0 & & 0 & & 0 & & & & 0 & & & & 0 & & 0 & & & & & 1 \\
\hline \multirow[t]{4}{*}{2} & 2 & 5 & 76 & 3 & 0 & 2 & 0 & 0 & 0 & & & & & 0 & & 0 & & & & & & 0 & & & & & 0 \\
\hline & 3 & 1 & 12 & 76 & 1 & 1 & 0 & 0 & 0 & 0 & & & & & & & & 0 & & & 0 & 0 & & 0 & 0 & & 0 \\
\hline & 4 & 0 & 4 & 6 & 73 & 4 & 0 & 0 & 0 & 0 & 0 & 0 & 0 & & 0 & 0 & & & 0 & 0 & & 0 & 0 & 0 & 0 & 0 & 0 \\
\hline & 5 & 1 & 8 & 2 & 8 & 59 & 0 & 0 & 0 & 0 & 0 & 0 & 0 & 0 & 0 & 0 & 0 & & & 0 & & 0 & & & & & 1 \\
\hline \multirow[t]{3}{*}{3} & 6 & 0 & 2 & 2 & 10 & 2 & 66 & 1 & 1 & 0 & 0 & 0 & 0 & 0 & 0 & 0 & & & 0 & 0 & 0 & 0 & 0 & 0 & & 0 & 0 \\
\hline & 7 & 0 & 1 & 0 & 1 & 1 & 1 & 62 & 0 & 0 & 0 & & 0 & 0 & & 0 & & & & 0 & & 0 & & 0 & & & 1 \\
\hline & 8 & 0 & 1 & 1 & 6 & 1 & 3 & 1 & 64 & 1 & & 0 & & & 0 & 0 & & 0 & 0 & 0 & 0 & 2 & 0 & 0 & & 0 & 1 \\
\hline \multirow[t]{4}{*}{4} & 9 & 0 & 0 & 0 & 1 & 0 & 1 & 1 & 1 & 66 & 1 & 0 & 1 & 1 & 1 & 0 & 0 & 0 & 0 & 0 & & 1 & 0 & 0 & 0 & 0 & 1 \\
\hline & 10 & & 0 & 0 & 4 & 1 & 6 & 0 & 1 & 3 & 63 & 1 & 0 & 0 & 1 & 0 & 0 & 0 & 0 & 0 & & 1 & 0 & 0 & & & 1 \\
\hline & 11 & & 0 & 1 & 2 & 2 & 5 & 0 & 1 & 1 & 2 & 60 & 0 & 0 & & 0 & & 0 & 0 & 0 & & 1 & & 0 & & & 1 \\
\hline & 12 & 0 & 0 & 0 & 1 & 0 & 1 & 0 & 0 & 2 & 1 & 0 & 77 & 0 & 0 & 0 & 1 & & 0 & 0 & 0 & 0 & & 0 & & 1 & 0 \\
\hline \multirow[t]{4}{*}{5} & 13 & & 0 & 0 & 0 & 0 & 0 & 0 & 1 & 4 & 1 & 0 & 1 & 65 & 1 & 0 & 0 & & 0 & 0 & & 1 & & 0 & & 0 & 1 \\
\hline & 14 & 0 & 0 & 0 & 1 & 1 & 2 & 1 & 1 & 8 & 1 & 1 & 1 & 1 & 58 & 0 & & 0 & & 0 & & 2 & 0 & 0 & & 0 & 0 \\
\hline & 15 & 0 & 0 & 0 & 0 & 0 & 0 & 0 & 0 & 4 & 0 & 0 & 0 & 0 & 0 & 62 & 1 & 1 & 2 & 0 & 0 & 1 & 0 & 0 & 0 & 0 & 0 \\
\hline & 16 & & 0 & & 0 & 0 & 0 & 0 & 0 & 1 & 0 & 0 & 7 & 0 & 0 & 2 & 72 & 0 & 1 & 0 & 0 & 0 & 0 & 0 & & 1 & 0 \\
\hline \multirow[t]{4}{*}{6} & 17 & & & & 1 & 0 & 1 & & 0 & 2 & 1 & 0 & 0 & 0 & 3 & 4 & 1 & 59 & 1 & 0 & & 1 & 0 & 0 & & & 0 \\
\hline & 18 & & & 0 & 0 & 0 & 0 & 0 & 0 & 2 & 0 & 0 & 0 & 2 & 0 & 5 & 1 & 1 & 57 & 0 & 0 & 0 & & 0 & 0 & 0 & 1 \\
\hline & 19 & 0 & 0 & & 0 & 0 & 0 & 0 & 0 & 2 & 0 & 0 & 0 & 0 & 0 & 4 & 0 & 0 & 0 & 62 & 1 & 1 & 0 & 0 & 1 & 0 & 0 \\
\hline & 20 & & & & 0 & 0 & 0 & & 0 & 0 & 0 & & 3 & 0 & 0 & 0 & 6 & 0 & 0 & 2 & 69 & 0 & 0 & 0 & 0 & 2 & 0 \\
\hline \multirow[t]{6}{*}{7} & 21 & 0 & 0 & 0 & 1 & 0 & 1 & 0 & 1 & 2 & 0 & 1 & 0 & 0 & 1 & 1 & 0 & 0 & 0 & 1 & 0 & 62 & 0 & 1 & 0 & 0 & 1 \\
\hline & 22 & & 0 & 0 & 1 & 0 & 1 & 0 & 0 & 1 & 0 & 0 & & 0 & 1 & 1 & 0 & 2 & 0 & 4 & & 2 & 63 & & & 0 & \\
\hline & 23 & 0 & 0 & 0 & 2 & 1 & 1 & 0 & 1 & 1 & & 0 & 0 & 0 & 0 & 1 & & 0 & 0 & & 0 & 2 & & 57 & & & 0 \\
\hline & 24 & & & & 1 & 0 & 0 & & 0 & 0 & & & 0 & 1 & 0 & 1 & 1 & & 4 & 5 & 0 & 1 & 0 & & 56 & 0 & 1 \\
\hline & 25 & 0 & 0 & 0 & 0 & 0 & 0 & 0 & 0 & 1 & 0 & 0 & 5 & 0 & 0 & 1 & 3 & 0 & 0 & 1 & 5 & 0 & 0 & 0 & 0 & 61 & 1 \\
\hline & 26 & 0 & 0 & 0 & 0 & 0 & 0 & 1 & 0 & 2 & 0 & 0 & 0 & 1 & 0 & 1 & 0 & & 1 & 2 & 0 & 1 & 0 & 0 & 0 & 1 & 53 \\
\hline
\end{tabular}

NOTES: The data are from Standard \& Poor's Execucomp database for 1992-2011. The number of observations is $118,375$. 
TABLE 3

TRANSITION PROBABILITY MATRIX FOR RANKS

\begin{tabular}{lcccccccc}
\hline \hline & Rank 1 & Rank 2 & Rank 3 & Rank 4 & Rank 5 & Rank 6 & Rank 7 & $N$ \\
\hline Rank 1 & 91.8 & 5.1 & 0.8 & 0.1 & 0.0 & 0.2 & 1.9 & 2,017 \\
Rank 2 & 2.7 & 96.3 & 0.4 & 0.1 & 0.1 & 0.0 & 0.4 & 29,870 \\
Rank 3 & 0.3 & 12.6 & 83.6 & 0.9 & 0.3 & 0.2 & 2.2 & 10,720 \\
Rank 4 & 0.0 & 1.7 & 3.8 & 88.8 & 2.8 & 0.5 & 2.4 & 25,426 \\
Rank 5 & 0.0 & 0.7 & 1.4 & 7.9 & 85.4 & 2.5 & 2.1 & 22,286 \\
Rank 6 & 0.0 & 0.4 & 0.9 & 3.5 & 7.1 & 84.6 & 3.4 & 18,360 \\
Rank 7 & 0.1 & 1.6 & 2.9 & 3.9 & 3.4 & 4.4 & 83.7 & 16,910 \\
$N$ & 2,737 & 31,158 & 11,002 & 25,775 & 21,681 & 16,986 & 16,250 & 125,589 \\
\hline
\end{tabular}

NOTES: The data are from Standard \& Poor's Execucomp database for 1992-2011. The number of observations is $125,589$. 
TABLE 4

SAMPLE OF EXECUTIVES

\begin{tabular}{|c|c|c|c|c|c|c|c|c|c|c|c|c|c|c|}
\hline & \multicolumn{3}{|c|}{ All Execucomp } & \multicolumn{11}{|c|}{ Execucomp ethnicity known } \\
\hline & \multirow[b]{2}{*}{ All } & \multirow[b]{2}{*}{ Male } & \multirow[b]{2}{*}{ Female } & \multicolumn{3}{|c|}{ All } & \multicolumn{3}{|c|}{ Caucasian } & \multirow{2}{*}{$\begin{array}{c}\text { Ethnic } \\
\text { All }\end{array}$} & \multirow{2}{*}{$\begin{array}{c}\begin{array}{c}\text { African } \\
\text { American }\end{array} \\
\text { All }\end{array}$} & \multirow{2}{*}{$\begin{array}{c}\text { Asian } \\
\text { All }\end{array}$} & \multirow{2}{*}{$\begin{array}{c}\text { Hispanic } \\
\text { All }\end{array}$} & \multirow{2}{*}{$\begin{array}{c}\text { Minority } \\
\text { All }\end{array}$} \\
\hline & & & & All & Male & Female & All & Male & Female & & & & & \\
\hline \multicolumn{15}{|c|}{ Panel A: Execucomp ${ }^{a}$} \\
\hline \# Executives & 39,379 & 37,120 & 2,259 & 8,126 & 7,734 & 392 & 7,694 & 7,334 & 360 & 432 & 114 & 211 & 107 & 792 \\
\hline \# Observations & 218,218 & 206,810 & 11,318 & 68,962 & 66,626 & 2,736 & 65,609 & 63,106 & 2,503 & 3,353 & 698 & 1,741 & 914 & 5,856 \\
\hline \multicolumn{15}{|c|}{ Panel B: All control variables available } \\
\hline \# Executives & 17,420 & 16,344 & 1076 & 5,772 & 5,469 & 303 & 5,426 & 5,151 & 275 & 346 & 90 & 169 & 87 & 621 \\
\hline \# Observations & 96,583 & 91,637 & 4,946 & 44,414 & 42,614 & 1,800 & 42,143 & 40,512 & 1,631 & 2,271 & 478 & 1,206 & 587 & 3,902 \\
\hline \multicolumn{15}{|c|}{ Panel C: All control variables available and rank known in subsequent year } \\
\hline \# Executives & 14,957 & 14,067 & 890 & 5,394 & 5,128 & 266 & 5,089 & 4,847 & 242 & 305 & 72 & 155 & 78 & 547 \\
\hline \# Observations & 76,184 & 72,519 & 3,665 & 37,681 & 36,242 & 1,439 & 35,816 & 34,512 & 1,304 & 1,865 & 368 & 1,010 & 487 & 3,169 \\
\hline
\end{tabular}

NOTES: The data are from Standard \& Poor's Execucomp database for 1992-2011.

${ }^{a}$ The following sub-categories are not tabulated or analyzed separately due to insufficient sample size: Ethnic female (32 executives / 233 observations); African American female ( 12 executives / 57 observations); Asian female ( 15 executives / 138 observations); Hispanic female ( 5 executives / 38 observations). 
TABLE 5

EXECUTIVE CHARACTERISTICS

\begin{tabular}{|c|c|c|c|c|c|c|c|c|c|c|c|c|c|c|}
\hline & All & $\begin{array}{c}\text { Caucasian } \\
\text { male }\end{array}$ & Minority & & Female & & $\begin{array}{l}\text { Ethnic } \\
\text { minority }\end{array}$ & & $\begin{array}{c}\text { African } \\
\text { American }\end{array}$ & & Asian & & Hispanic & \\
\hline Variable & Mean & Mean & Mean & $t(z)$-test & Mean & $t(z)$-test & Mean & $t(z)$-test & Mean & $t(z)$-test & Mean & $t(z)$-test & Mean & $t(z)$-test \\
\hline Rank 1 & 0.04 & 0.04 & 0.01 & $8.98 * * *$ & 0.01 & $7.06 * * *$ & 0.01 & $6.32 * * *$ & 0.01 & $3.88 * * *$ & 0.01 & $4.64 * * *$ & 0.02 & $2.37 * *$ \\
\hline Rank 2 & 0.51 & 0.52 & 0.35 & $20.33 * * *$ & 0.26 & $22.30 * * *$ & 0.42 & $9.32 * * *$ & 0.25 & $11.86^{* * *}$ & 0.49 & $2.30 * *$ & 0.43 & $4.70 * * *$ \\
\hline Rank 3 & 0.13 & 0.13 & 0.13 & 1.23 & 0.12 & 1.02 & 0.13 & 0.46 & 0.13 & -0.07 & 0.13 & 0.52 & 0.13 & 0.24 \\
\hline Rank 4 & 0.13 & 0.12 & 0.19 & $-11.34 * * *$ & 0.23 & $-12.61 * * *$ & 0.16 & $-4.71 * * *$ & 0.18 & $-3.58 * * *$ & 0.15 & $-2.41 * *$ & 0.16 & $-2.79 * * *$ \\
\hline Rank 5 & 0.08 & 0.07 & 0.14 & $-15.68 * * *$ & 0.18 & $-17.12 * * *$ & 0.11 & $-7.60 * * *$ & 0.20 & $-10.74 * * *$ & 0.09 & $-2.54 * * *$ & 0.09 & $-2.02 * *$ \\
\hline Rank 6 & 0.04 & 0.04 & 0.06 & $-8.86 * * *$ & 0.08 & $-8.75 * * *$ & 0.06 & $-4.90 * * *$ & 0.09 & $-6.80 * * *$ & 0.05 & $-2.14 * *$ & 0.04 & -0.68 \\
\hline Rank 7 & 0.07 & 0.07 & 0.11 & $-9.96 * * *$ & 0.13 & $-9.45 * * *$ & 0.10 & $-6.09 * * *$ & 0.14 & $-5.51 * * *$ & 0.08 & -1.51 & 0.13 & $-5.17 * * *$ \\
\hline Bachelor's & 0.98 & 0.98 & 0.98 & $-1.64 *$ & 0.98 & -1.57 & 0.98 & -1.32 & 1.00 & $-3.30 * * *$ & 0.98 & 0.23 & 0.98 & -0.01 \\
\hline Master's & 0.53 & 0.53 & 0.61 & $-10.14 * * *$ & 0.52 & 0.30 & 0.69 & $-14.71 * * *$ & 0.67 & $-6.11 * * *$ & 0.73 & $-14.02 * * *$ & 0.60 & $-3.75^{* * *}$ \\
\hline $\mathrm{PhD}$ & 0.08 & 0.07 & 0.11 & $-8.98 * * *$ & 0.07 & 0.80 & 0.15 & $-13.62 * * *$ & 0.05 & $1.67 *$ & 0.22 & $-19.63 * * *$ & 0.08 & -0.42 \\
\hline Age & 53.83 & 54.10 & 51.05 & $24.32 * * *$ & 50.23 & $23.16 * * *$ & 51.69 & $14.53 * * *$ & 51.93 & 7.00 *** & 51.61 & $10.58 * * *$ & 51.65 & $7.67 * * *$ \\
\hline Tenure & 17.54 & 17.86 & 14.24 & $20.55 * * *$ & 13.04 & $20.06 * * *$ & 14.97 & $12.57 * * *$ & 13.71 & $8.22 * * *$ & 13.78 & $15.06 * * *$ & 18.45 & -1.18 \\
\hline Experience & 31.99 & 32.28 & 28.94 & $27.07 * * *$ & 28.42 & $23.19 * * *$ & 29.31 & $18.21 * * *$ & 30.00 & $7.37 * * *$ & 28.83 & $15.13 * * *$ & 29.73 & $8.06 * * *$ \\
\hline Communications, HR, or legal & 0.02 & 0.02 & 0.05 & $-11.54 * * *$ & 0.07 & $-14.61 * * *$ & 0.03 & $-4.55 * * *$ & 0.10 & $-13.31 * * *$ & 0.01 & 1.44 & 0.01 & 0.95 \\
\hline \# Observations & 44,414 & 40,512 & 3,902 & & 1,800 & & 2,271 & & 478 & & 1,206 & & 587 & \\
\hline
\end{tabular}

NOTES: The data are from Standard \& Poor's Execucomp database for 1992-2011.The $t$-test is used for differences in age, tenure and experience whilst the $z$-test is used for differences in rank, education levels, and functional area. $* * *, * * *$ indicate significance at the $0.01,0.05$, and 0.10 percent levels respectively, from two-sided tests of the difference of the respective variable between Caucasian males and minority groups. 
TABLE 6

MOBILITY EVENTS By MINORITY STATUS

\begin{tabular}{|c|c|c|c|c|c|c|}
\hline & \multicolumn{2}{|c|}{ No event } & \multicolumn{2}{|c|}{ Mobility event } & \multirow[t]{2}{*}{$N$} & \multirow[t]{2}{*}{$z$-test } \\
\hline & $N$ & Proportion & $N$ & Proportion & & \\
\hline \multicolumn{7}{|l|}{ Panel A: Promotion ${ }^{a}$} \\
\hline All & 32,956 & 0.9014 & 3,603 & 0.0986 & 36,559 & \\
\hline Caucasian male & 30,122 & 0.9012 & 3,301 & 0.0988 & 33,423 & \\
\hline Minority & 2,834 & 0.9037 & 302 & 0.0963 & 3,136 & 0.44 \\
\hline Female & 1,297 & 0.9083 & 131 & 0.0917 & 1,428 & 0.87 \\
\hline Ethnic minority & 1,657 & 0.8991 & 186 & 0.1009 & 1,843 & -0.30 \\
\hline African American & 331 & 0.9019 & 36 & 0.0981 & 367 & 0.04 \\
\hline Asian & 901 & 0.9037 & 96 & 0.0963 & 997 & 0.26 \\
\hline Hispanic & 425 & 0.8873 & 54 & 0.1127 & 479 & -1.02 \\
\hline \multicolumn{7}{|l|}{ Panel B: Demotion ${ }^{b}$} \\
\hline All & 34,194 & 0.9770 & 805 & 0.0230 & 34,999 & \\
\hline Caucasian male & 31,458 & 0.9782 & 700 & 0.0218 & 32,158 & \\
\hline Minority & 2,736 & 0.9630 & 105 & 0.0370 & 2,841 & $-5.18 * * *$ \\
\hline Female & 1,226 & 0.9578 & 54 & 0.0422 & 1,280 & $-4.83 * * *$ \\
\hline Ethnic minority & 1,623 & 0.9666 & 56 & 0.0334 & 1,679 & $-3.13 * * *$ \\
\hline African American & 304 & 0.9412 & 19 & 0.0588 & 323 & $-4.50 * * *$ \\
\hline Asian & 907 & 0.9721 & 26 & 0.0279 & 933 & -1.25 \\
\hline Hispanic & 412 & 0.9740 & 11 & 0.0260 & 423 & -0.59 \\
\hline \multicolumn{7}{|l|}{ Panel C: Exit } \\
\hline All & 40,283 & 0.9376 & 2,679 & 0.0624 & 42,962 & \\
\hline Caucasian male & 36,813 & 0.9387 & 2,406 & 0.0613 & 39,219 & \\
\hline Minority & 3,470 & 0.9271 & 273 & 0.0729 & 3,743 & $-2.80 * * *$ \\
\hline Female & 1,631 & 0.9204 & 141 & 0.0796 & 1,772 & $-3.11 * * *$ \\
\hline Ethnic minority & 1,985 & 0.9311 & 147 & 0.0689 & 2,132 & -1.42 \\
\hline African American & 444 & 0.8898 & 55 & 0.1102 & 499 & $-4.50 * * *$ \\
\hline Asian & 1,016 & 0.9469 & 57 & 0.0531 & 1,073 & 1.11 \\
\hline Hispanic & 525 & 0.9375 & 35 & 0.0625 & 560 & -0.11 \\
\hline
\end{tabular}

NOTES: The data are from Standard \& Poor's Execucomp database for 1992-2011. ***, **, * indicate significance at the $0.01,0.05$, and 0.10 percent levels respectively, from two-sided tests of the difference of the respective variable between Caucasian males and other groups.

${ }^{a}$ Promotion is not defined for rank 1 executives.

${ }^{\mathrm{b}}$ Demotion is not defined for rank 7 executives. 
TABLE 7

LOGIT REGRESSIONS OF THE EFFECT OF MINORITY STATUS ON PROMOTION

\begin{tabular}{|c|c|c|c|}
\hline Independent variable & (1) & (2) & (3) \\
\hline Constant & $\begin{array}{c}1.655 * * \\
(0.647)\end{array}$ & $\begin{array}{l}1.668 * * \\
(0.646)\end{array}$ & $\begin{array}{c}1.635 * * * \\
(0.647)\end{array}$ \\
\hline Minority & $\begin{array}{c}-0.338 * * * \\
(0.068)\end{array}$ & & \\
\hline Female & & $\begin{array}{c}-0.541 * * * \\
(0.099)\end{array}$ & $\begin{array}{c}-0.539 * * * \\
(0.099)\end{array}$ \\
\hline Ethnic & & $\begin{array}{l}-0.112 \\
(0.086)\end{array}$ & \\
\hline African American & & & $\begin{array}{c}-0.431 * * \\
(0.187)\end{array}$ \\
\hline Asian & & & $\begin{array}{l}-0.038 \\
(0.118)\end{array}$ \\
\hline Hispanic & & & $\begin{array}{c}0.005 \\
(0.156)\end{array}$ \\
\hline Rank 2 & $\begin{array}{c}-2.537 * * * \\
(0.069)\end{array}$ & $\begin{array}{c}-2.539 * * * \\
(0.069)\end{array}$ & $\begin{array}{c}-2.539 * * * \\
(0.069)\end{array}$ \\
\hline Rank 3 & $\begin{array}{c}-0.330 * * * \\
(0.061)\end{array}$ & $\begin{array}{c}-0.330 * * * \\
(0.061)\end{array}$ & $\begin{array}{c}-0.329 * * * \\
(0.061)\end{array}$ \\
\hline Rank 4 & $\begin{array}{c}-0.652 * * * \\
(0.065)\end{array}$ & $\begin{array}{c}-0.650 * * * \\
(0.065)\end{array}$ & $\begin{array}{c}-0.651 * * * \\
(0.065)\end{array}$ \\
\hline Rank 5 & $\begin{array}{c}-0.239 * * * \\
(0.069)\end{array}$ & $\begin{array}{c}-0.234 * * * \\
(0.069)\end{array}$ & $\begin{array}{c}-0.231 * * * \\
(0.069)\end{array}$ \\
\hline Rank 6 & $\begin{array}{c}0.020 \\
(0.082)\end{array}$ & $\begin{array}{c}0.024 \\
(0.082)\end{array}$ & $\begin{array}{c}0.028 \\
(0.082)\end{array}$ \\
\hline Bachelor's & $\begin{array}{c}0.325 * * \\
(0.140)\end{array}$ & $\begin{array}{c}0.333 * * \\
(0.140)\end{array}$ & $\begin{array}{l}0.337 * * \\
(0.140)\end{array}$ \\
\hline Master's & $\begin{array}{l}-0.014 \\
(0.040)\end{array}$ & $\begin{array}{l}-0.019 \\
(0.040)\end{array}$ & $\begin{array}{l}-0.019 \\
(0.040)\end{array}$ \\
\hline $\mathrm{PhD}$ & $\begin{array}{l}-0.067 \\
(0.080)\end{array}$ & $\begin{array}{l}-0.073 \\
(0.080)\end{array}$ & $\begin{array}{l}-0.077 \\
(0.080)\end{array}$ \\
\hline Age & $\begin{array}{c}-0.121 * * * \\
(0.021)\end{array}$ & $\begin{array}{c}-0.121 * * * \\
(0.021)\end{array}$ & $\begin{array}{c}-0.121 * * * \\
(0.021)\end{array}$ \\
\hline $\mathrm{Age}^{2}$ & $\begin{array}{c}0.001 * * * \\
(0.000)\end{array}$ & $\begin{array}{c}0.001 * * * \\
(0.000)\end{array}$ & $\begin{array}{c}0.001 * * * \\
(0.000)\end{array}$ \\
\hline Tenure & $\begin{array}{c}0.009 * * * \\
(0.002)\end{array}$ & $\begin{array}{c}0.009 * * * \\
(0.002)\end{array}$ & $\begin{array}{c}0.009 * * * \\
(0.002)\end{array}$ \\
\hline Communications, HR, or legal & $\begin{array}{c}-0.397 * * * \\
(0.123)\end{array}$ & $\begin{array}{c}-0.392 * * * \\
(0.123)\end{array}$ & $\begin{array}{c}-0.381 * * * \\
(0.123)\end{array}$ \\
\hline Firm change & $\begin{array}{c}2.383 * * * \\
(0.110)\end{array}$ & $\begin{array}{c}2.384 * * * \\
(0.110)\end{array}$ & $\begin{array}{c}2.386 * * * \\
(0.110)\end{array}$ \\
\hline Log (Assets) & $\begin{array}{c}0.003 \\
(0.014)\end{array}$ & $\begin{array}{c}0.001 \\
(0.014)\end{array}$ & $\begin{array}{c}0.003 \\
(0.014)\end{array}$ \\
\hline Share return & $\begin{array}{l}-0.081 * \\
(0.046)\end{array}$ & $\begin{array}{l}-0.081 * \\
(0.046)\end{array}$ & $\begin{array}{l}-0.081 * \\
(0.046)\end{array}$ \\
\hline $\begin{array}{l}\text { Pseudo } R^{2} \\
\text { Observations }\end{array}$ & $\begin{array}{l}0.1520 \\
36,550\end{array}$ & $\begin{array}{l}0.1524 \\
36,550\end{array}$ & $\begin{array}{l}0.1525 \\
36,550\end{array}$ \\
\hline
\end{tabular}

NotES: The data are from Standard \& Poor's Execucomp database for 1992-2011. ***,**, * indicate significance at the $0.01,0.05$, and 0.10 percent levels respectively. Standard errors are in parentheses. Each model includes year dummy variables and controls for industry effects measured at the two digit SIC level. 
TABLE 8

LOGIT REGRESSIONS OF THE EFFECT OF MINORITY STATUS ON DEMOTION

\begin{tabular}{|c|c|c|c|}
\hline Independent variable & $(1)$ & $(2)$ & (3) \\
\hline Constant & $\begin{array}{c}-4.480 * * * \\
(1.312)\end{array}$ & $\begin{array}{c}-4.471 * * * \\
(1.313)\end{array}$ & $\begin{array}{c}-4.442 * * * \\
(1.314)\end{array}$ \\
\hline Minority & $\begin{array}{c}0.275^{* *} \\
(0.115)\end{array}$ & & \\
\hline Female & & $\begin{array}{c}0.241 \\
(0.155)\end{array}$ & $\begin{array}{c}0.236 \\
(0.155)\end{array}$ \\
\hline Ethnic & & $\begin{array}{l}0.274 * \\
(0.150)\end{array}$ & \\
\hline African American & & & $\begin{array}{c}0.555 * * \\
(0.255)\end{array}$ \\
\hline Asian & & & $\begin{array}{c}0.179 \\
(0.216)\end{array}$ \\
\hline Hispanic & & & $\begin{array}{c}0.110 \\
(0.318)\end{array}$ \\
\hline Rank 1 & $\begin{array}{c}0.670 * * * \\
(0.191)\end{array}$ & $\begin{array}{c}0.670 * * * \\
(0.191)\end{array}$ & $\begin{array}{c}0.674 * * * \\
(0.191)\end{array}$ \\
\hline Rank 2 & $\begin{array}{c}-2.108 * * * \\
(0.157)\end{array}$ & $\begin{array}{c}-2.109 * * * \\
(0.157)\end{array}$ & $\begin{array}{c}-2.105 * * * \\
(0.157)\end{array}$ \\
\hline Rank 3 & $\begin{array}{c}-0.872 * * * \\
(0.157)\end{array}$ & $\begin{array}{c}-0.873 * * * \\
(0.157)\end{array}$ & $\begin{array}{c}-0.868 * * * \\
(0.157)\end{array}$ \\
\hline Rank 4 & $\begin{array}{l}-0.147 \\
(0.141)\end{array}$ & $\begin{array}{l}-0.147 \\
(0.141)\end{array}$ & $\begin{array}{l}-0.141 \\
(0.141)\end{array}$ \\
\hline Rank 5 & $\begin{array}{c}-0.318 * * \\
(0.154)\end{array}$ & $\begin{array}{c}-0.318 * * \\
(0.154)\end{array}$ & $\begin{array}{c}-0.314 * * \\
(0.154)\end{array}$ \\
\hline Bachelor's & $\begin{array}{c}0.105 \\
(0.253)\end{array}$ & $\begin{array}{c}0.105 \\
(0.253)\end{array}$ & $\begin{array}{c}0.102 \\
(0.253)\end{array}$ \\
\hline Master's & $\begin{array}{c}-0.171 * * \\
(0.080)\end{array}$ & $\begin{array}{c}-0.172 * * \\
(0.080)\end{array}$ & $\begin{array}{c}-0.172 * * \\
(0.080)\end{array}$ \\
\hline $\mathrm{PhD}$ & $\begin{array}{l}-0.069 \\
(0.158)\end{array}$ & $\begin{array}{l}-0.071 \\
(0.158)\end{array}$ & $\begin{array}{l}-0.063 \\
(0.159)\end{array}$ \\
\hline Age & $\begin{array}{c}0.017 \\
(0.038)\end{array}$ & $\begin{array}{c}0.017 \\
(0.038)\end{array}$ & $\begin{array}{c}0.017 \\
(0.038)\end{array}$ \\
\hline $\mathrm{Age}^{2}$ & $\begin{array}{c}0.000 \\
(0.000)\end{array}$ & $\begin{array}{c}0.000 \\
(0.000)\end{array}$ & $\begin{array}{c}0.000 \\
(0.000)\end{array}$ \\
\hline Tenure & $\begin{array}{l}-0.003 \\
(0.004)\end{array}$ & $\begin{array}{l}-0.003 \\
(0.004)\end{array}$ & $\begin{array}{l}-0.003 \\
(0.004)\end{array}$ \\
\hline Communications, HR, or legal & $\begin{array}{c}0.128 \\
(0.198)\end{array}$ & $\begin{array}{c}0.127 \\
(0.198)\end{array}$ & $\begin{array}{c}0.112 \\
(0.199)\end{array}$ \\
\hline Firm change & $\begin{array}{c}2.378 * * * \\
(0.141)\end{array}$ & $\begin{array}{c}2.377 * * * \\
(0.141)\end{array}$ & $\begin{array}{c}2.377 * * * \\
(0.141)\end{array}$ \\
\hline Log (Assets) & $\begin{array}{c}0.084 * * * \\
(0.027)\end{array}$ & $\begin{array}{c}0.084 * * * \\
(0.027)\end{array}$ & $\begin{array}{c}0.081 * * * \\
(0.028)\end{array}$ \\
\hline Share return & $\begin{array}{c}0.014 \\
(0.088)\end{array}$ & $\begin{array}{c}0.014 \\
(0.088)\end{array}$ & $\begin{array}{c}0.013 \\
(0.088)\end{array}$ \\
\hline $\begin{array}{l}\text { Pseudo } R^{2} \\
\text { Observations }\end{array}$ & $\begin{array}{l}0.1351 \\
34,536\end{array}$ & $\begin{array}{l}0.1351 \\
34,536\end{array}$ & $\begin{array}{l}0.1353 \\
34,536\end{array}$ \\
\hline
\end{tabular}

NOTES: The data are from Standard \& Poor's Execucomp database for 1992-2011.***,**,* indicate significance at the $0.01,0.05$, and 0.10 percent levels respectively. Standard errors are in parentheses. Each model includes year dummy variables and controls for industry effects measured at the two digit SIC level. 
TABLE 9

LOGIT REGRESSIONS OF THE EFFECT OF MINORITY STATUS ON EXIT

\begin{tabular}{|c|c|c|c|}
\hline Independent variable & $(1)$ & $(2)$ & (3) \\
\hline Constant & $\begin{array}{c}-11.025^{* * * *} \\
(0.779)\end{array}$ & $\begin{array}{c}-10.629 * * * \\
(0.789)\end{array}$ & $\begin{array}{c}-11.048 * * * \\
(0.782)\end{array}$ \\
\hline Minority & $\begin{array}{c}0.311 * * * \\
(0.071)\end{array}$ & & \\
\hline Female & & $\begin{array}{c}0.350 * * * \\
(0.098)\end{array}$ & $\begin{array}{c}0.451 * * * \\
(0.097)\end{array}$ \\
\hline Ethnic & & $\begin{array}{c}0.079 \\
(0.094)\end{array}$ & \\
\hline African American & & & $\begin{array}{c}0.438 * * * \\
(0.155)\end{array}$ \\
\hline Asian & & & $\begin{array}{l}-0.057 \\
(0.147)\end{array}$ \\
\hline Hispanic & & & $\begin{array}{c}0.108 \\
(0.185)\end{array}$ \\
\hline Rank 1 & $\begin{array}{c}0.663 * * * \\
(0.101)\end{array}$ & $\begin{array}{c}0.619 * * * \\
(0.101)\end{array}$ & $\begin{array}{c}0.662 * * * \\
(0.101)\end{array}$ \\
\hline Rank 2 & $\begin{array}{c}-0.874 * * * \\
(0.077)\end{array}$ & $\begin{array}{c}-0.902 * * * \\
(0.077)\end{array}$ & $\begin{array}{c}-0.872 * * * \\
(0.077)\end{array}$ \\
\hline Rank 3 & $\begin{array}{c}-0.319 * * * \\
(0.086)\end{array}$ & $\begin{array}{c}-0.315^{* * *} \\
(0.086)\end{array}$ & $\begin{array}{c}-0.322 * * * \\
(0.086)\end{array}$ \\
\hline Rank 4 & $\begin{array}{c}-0.240 * * * \\
(0.086)\end{array}$ & $\begin{array}{c}-0.252 * * * \\
(0.087)\end{array}$ & $\begin{array}{c}-0.243 * * * \\
(0.086)\end{array}$ \\
\hline Rank 5 & $\begin{array}{l}-0.136 \\
(0.096)\end{array}$ & $\begin{array}{l}-0.154 \\
(0.096)\end{array}$ & $\begin{array}{l}-0.145 \\
(0.096)\end{array}$ \\
\hline Rank 6 & $\begin{array}{l}-0.159 \\
(0.125)\end{array}$ & $\begin{array}{l}-0.169 \\
(0.125)\end{array}$ & $\begin{array}{l}-0.169 \\
(0.125)\end{array}$ \\
\hline Bachelor's & $\begin{array}{l}0.261^{*} \\
(0.157)\end{array}$ & $\begin{array}{l}0.269 * \\
(0.157)\end{array}$ & $\begin{array}{c}0.251 \\
(0.157)\end{array}$ \\
\hline Master's & $\begin{array}{c}0.070 \\
(0.045)\end{array}$ & $\begin{array}{c}0.058 \\
(0.045)\end{array}$ & $\begin{array}{c}0.072 \\
(0.045)\end{array}$ \\
\hline $\mathrm{PhD}$ & $\begin{array}{c}-0.201 * * \\
(0.081)\end{array}$ & $\begin{array}{l}-0.141 * \\
(0.082)\end{array}$ & $\begin{array}{c}-0.185^{* *} \\
(0.081)\end{array}$ \\
\hline Age & $\begin{array}{c}0.198 * * * \\
(0.024)\end{array}$ & $\begin{array}{c}0.194 * * * \\
(0.024)\end{array}$ & $\begin{array}{c}0.200 * * * \\
(0.024)\end{array}$ \\
\hline $\mathrm{Age}^{2}$ & $\begin{array}{c}-0.001 * * * \\
(0.000)\end{array}$ & $\begin{array}{c}-0.001 * * * \\
(0.000)\end{array}$ & $\begin{array}{c}-0.001 * * * \\
(0.000)\end{array}$ \\
\hline Tenure & $\begin{array}{c}-0.009^{* * * *} \\
(0.002)\end{array}$ & $\begin{array}{c}-0.008 * * * \\
(0.002)\end{array}$ & $\begin{array}{c}-0.009 * * * \\
(0.002)\end{array}$ \\
\hline Communications, HR, or legal & $\begin{array}{c}0.086 \\
(0.133)\end{array}$ & $\begin{array}{c}0.082 \\
(0.133)\end{array}$ & $\begin{array}{c}0.053 \\
(0.134)\end{array}$ \\
\hline Log (Assets) & $\begin{array}{c}0.143 * * * \\
(0.015)\end{array}$ & $\begin{array}{c}0.129 * * * \\
(0.015)\end{array}$ & $\begin{array}{c}0.142 * * * \\
(0.015)\end{array}$ \\
\hline Share return & $\begin{array}{c}-0.434 * * * \\
(0.053)\end{array}$ & $\begin{array}{c}-0.370 * * * \\
(0.057)\end{array}$ & $\begin{array}{c}-0.435 * * * \\
(0.053)\end{array}$ \\
\hline $\begin{array}{l}\text { Pseudo } R^{2} \\
\text { Observations }\end{array}$ & $\begin{array}{l}0.0860 \\
36,792\end{array}$ & $\begin{array}{l}0.0933 \\
36,792\end{array}$ & $\begin{array}{l}0.0865 \\
36,792\end{array}$ \\
\hline
\end{tabular}

NOTES: The data are from Standard \& Poor's Execucomp database for 1992-2011. ***,**,* indicate significance at the $0.01,0.05$, and 0.10 percent levels respectively. Standard errors are in parentheses. Each model includes year dummy variables and controls for industry effects measured at the two digit SIC level. 